\title{
THE CULTURAL RELEVANCE OF INDONESIAN PHRASEOLOGICAL UNITS AS CONTRASTED WITH POLISH
}

\author{
Przemysław Wiatrowski*
}

\begin{abstract}
ABSTRAK
Makalah ini membahas frasa-frasa ungkapan tetap (set phrases) yang belum pernah diteliti oleh para peneliti Polandia. Tujuannya adalah menganalisis ungkapan-ungkapan yang menyatakan kekhasan budaya masyarakat pengguna bahasa Indonesia. Secara khusus, penulis membahas dua kategori ungkapan-ungkapan kata ganda. Salah satunya adalah kombinasi leksikal yang mempertahankan ciri nyata masyarakat pengguna bahasa Indonesia. Ini tercermin dalam satu sistem konotasi leksikal yang diperoleh dari proses pembentukan makna idiom-idiom. Adapun yang kedua adalah seperangkat ungkapan yang terdiri atas satuan-satuan yang menunjukkan kekhasan budaya Indonesia. Relevansi budaya dari kombinasi kata ganda dalam bahasa Indonesia diteliti dengan perbandingan latar belakang bahasa Polandia. Dengan menguji bahan-bahan penelitian yang bersumber dari kamus frasa dan kolokasi dari kamus-kamus umum bahasa Indonesia, peneliti memperoleh wawasan tentang cara berpikir dan menanggapi kenyataan yang melekat dalam bahasa dan dalam pengalaman kolektif anggota masyarakat penutur bahasa Indonesia.
\end{abstract}

Kata kunci: bahasa Indonesia, bahasa Polandia, konotasi, ungkapan kata ganda, relevansi budaya, relativitas bahasa

\begin{abstract}
This article discusses Indonesian set phrases, a research area not previously investigated by Polish scholars. The aim is to analyze expressions which reveal the cultural specificity of the Indonesian speech community. Specifically, the author is concerned with two categories of multiword expressions. One of them is lexical combinations which preserve observations characteristic of the Indonesian speech community. These are reflected in a system of lexical connotations drawn upon in the process of semantic motivation of idioms. The other is expressions made up of units which are specific to Indonesian culture. The cultural relevance of Indonesian multi-word combinations is examined against the background of the Polish language. By examining research material derived from dictionaries of phrases and collocations and general dictionaries of the Indonesian language, the author provides insights into the way of thinking and responding to reality which is embedded in the language and in the collective experience of members of the Indonesian community.
\end{abstract}

Keywords: connotation, cultural relevance, Indonesian language, linguistic relativity, multi-word expression, Polish language

\footnotetext{
* Faculty of Polish and Classical Philology, Institute of Polish Philology, Department of Contemporary Polish Language Grammar and Onomastics, Adam Mickiewicz University, Poznań, Poland.
} 


\section{INTRODUCTION}

According to Lewicki and Pajdzińska (2001:328-329), "Badając związki języka z historią i kulturą narodu, trudno wprost przecenić materiał frazeologiczny. [...] frazeologizmy odbijają dzieje narodu, świat, w którym żył, stosunki społeczno-polityczne, obyczajowe, [...] stanowią świadectwo przynależności do pewnego kręgu kulturowego. Zasób frazeologiczny dostarcza również wielu ciekawych, wręcz spektakularnych dowodów, że te same fakty, zjawiska czy zachowania mogą być różnie opisywane w różnych językach" ["In researching links between languages and the histories and cultures of the nations that use them, one can hardly overestimate the significance of phraseological material. [...] phrasemes reflect the histories of nations, their world, social and political relations and customs [...], all of which are indicative of belonging to a specific culture. Set phrases also provide much interesting and even spectacular evidence that different languages may describe the same facts, phenomena and behaviors in different ways"]. "Wszystko to zawarte i utrwalone w strukturze leksykalnej i semantycznej frazeologizmu staje się jeszcze bardziej wyraziste, gdy mamy do czynienia $\mathrm{z}$ odległymi od siebie kulturami, z odległymi od siebie językami" ["The concepts established and preserved in the lexical and semantic structures of fixed expressions become all the more distinctive when we compare remote cultures and languages"] (Lisowski, 2004:189). These observations set the stage for an analysis of phraseological units that reflect the cultural specificity of the Indonesian speech community.

The topic concerns two sets of verbal associations. One comprises multi-word expressions driven by observations that are distinctive for a specific speech community. This view of a non-linguistic reality specific to the Indonesian community is reflected in lexical connotations (see for instance Chaer, 2007:152-153; Pateda, 2010:178-183; Berthemet, 2011:230) which are applied in the process of semantic motivation of multi-word expressions (see for instance Lewicki, 2003:259-274, 275292; Dobrovol'skij \& Piirainen, 2005; Berthemet, 2011:230). The other set of phrases consists of idioms used to express concepts specific to Indonesian culture based on designations that are foreign to Polish culture. Since the mechanism of ascertaining relevance relies on oppositions, the linguistic and cultural frame of reference used in the analysis is that of the Polish language.

Contrastive analysis is very appropriate to compare two languages of either the same family or different family (Ana, 2014:85). The Indonesian language (used by an estimated 200 to 270 million people, depending on the method of counting) and Polish (which is a mother tongue for approximately 40 million Poles) differ in both their genetics and typology. Indonesian belongs to the family of Austronesian languages (Keraf, 1990:57; Sneddon, 2003:22-32; Adelaar, 2005:826), whereas Polish is a Slavic language, a member of the Indo-European family (Majewicz, 1989:21-39). Typologically, Indonesian, like many other Austronesian languages, is an agglutinative language (Quinn, 2001:vii). Polish is a fusional language (like most Slavic languages), with so-called synthetic inflection. Its declension depends on number, gender and case. The inflection of verbs (conjugation) depends on person, number, tense, voice, mood and aspect (perfective or imperfective).

Similarly to Polish, Indonesian offers a moderately rich phonological system (Alvi, Dardjowidjojo, Lapoliwa, Moeliono, 2003:5576; Muslich, 2008; Chaer, 2011:38-39; 2013a; Indonesian vowels and their allophones have been described by Wijana, 2003). Depending on the method adopted for calculation, Polish has between 37 and 42 phonemes. In both of the languages, consonants outnumber vowels. Both are also non-prosodic. Their word stress is dynamic, falling generally on the penultimate syllable. In terms of word order, both Indonesian and Polish are predominantly of SVO type (subject, verb, object). Both languages use the Latin alphabet. 
Due to the country's ethnic diversity, Indonesians do not speak Indonesian as a first language (Ana, 2014:85). Indonesia is home to hundreds of local and regional languages. This means that Indonesians are a bilingual people. Note also that linguists disagree as to the number of languages in use in Indonesia (Jedamski, 1987:3; Sneddon, 2003:5; see also Forshee, 2006:7). Poland has no such diversity. Apart from the Polish language, there is an ethnolect known as Kashubian, used by an ethnic minority which populates the country's northern region of Pomerania.

No Indonesian phraseological research has so far been conducted in Poland. No knowledge is available concerning the Indonesian language's stock of phrases, the formal differentiation of set phrases, their semantic microsystems and ethnic/ cultural markings. No comparative studies have been undertaken on the phraseology of Indonesian and Polish. The usual focus of such studies has been on comparing Polish with other Slavic languages (such as Russian, Czech, Slovak, Croatian, Kashubian, Sorbian and Bulgarian) as well as certain non-Slavic languages (primarily French, English, German, Italian and Dutch) (Zaręba \& Szpila, 2007).

A confrontation of the phraseologies of Indonesian and Polish, which are languages used by communication communities that differ sharply both geographically and culturally, sheds light on the similarities and differences between the two languages which need to be accounted for in preparing a bilingual dictionary of phrases. Moreover a juxtaposition of Indonesian and Polish set phrases produces interesting observations concerning the views of the world which emerge through the linguistic environment. Such comparisons also have undoubted value for the practice of translation and language teaching. Ana (2014:85-86) explains that this synchronic method "especially gives practical solution for language learning and translation problems. Therefore, contrastive analysis can be used to deal with, or solve the difficulty of language learning, as well as predict the difficulties so that the interference from the first language can be minimized".

The research problem so defined falls within the scope of cultural linguistics, whose aims, tenets and main research interests have been described in detail by Anusiewicz (1995; see also e.g. Burszta, 1986; Bartmiński, 2007, 2009). The primary precept of the field is the premise that in addition to being a means of expressing and communicating information, language may serve additionally, or perhaps primarily, as a medium, a construct and a process containing (presenting) the cultural heritage of a given speech community, which additionally serves as an expression of the community's social practices and experience as preserved and accumulated over multiple generations. Language is also a medium used to transmit and collect values, judgments and evaluations as well as standards of conduct which underlie behaviors, actions, beliefs and ethical and normative systems of specific communities (nations). Viewed in this manner, language is a central component of culture and a reflection of its experience and the cultural processes of individuals (the community) in specific realities. This is because language contains some of the most essential features of culture as a whole; it is a collection of its resources, a record of ways of conceptualizing and categorizing the reality prevalent in a given culture, and of the culture's methods of axiologizing, perceiving and responding to reality. Language is also seen as a tool, a means and a factor for learning the world as well as an instrument for communicating within the world (Anusiewicz, 1995:12; see also e.g. Nur, 2011:270-271).

The phraseological material presented in the present article is derived from the following lexicographic sources, which are available in Poland: (1) Abdul Chaer, Kamus Ungkapan Bahasa Indonesia (2002); (2) Jusuf S. Badudu, Kamus Ungkapan Bahasa Indonesia (2009). Examples have also been sourced from two 
general dictionaries of the Indonesian language: Kamus Bahasa Indonesia (2008) and Kamus Besar Bahasa Indonesia (2008).

Polish multi-word expressions are taken from Stanisław Skorupka, Stownik frazeologiczny języka polskiego (Dictionary of Polish Phrases and Collocations) (1967), Stanisław Bąba, Jarosław Liberek, Stownik frazeologiczny wspótczesnej polszczyzny (Dictionary of Contemporary Polish Phrases and Collocations) (2001), and Wielki stownik frazeologiczny PWN z przystowiami (PWN Great Dictionary of Phrases and Proverbs) produced by Anna Kłosińska, Elżbieta Sobol and Anna Stankiewicz (2005). The author additionally referred to Stownik polszczyzny potocznej (Dictionary of Colloquial Polish) (Anusiewicz \& Skawiński, 1996).

For the purposes of the study, phraseological units are defined very broadly. The term is taken to include common multi-word expressions, that is, as proposed by Lewicki and Pajdzińska (2001:315): "społecznie utrwalone połączenia wyrazów wykazujące nieregularność pod jakimś względem, np.: w ich składzie występują wyrazy lub formy wyrazów nie wchodzące w swobodne związki składniowe; znaczenie frazeologizmu nie wynika ze znaczeń komponentów; naruszone bywają zasady łączliwości wyrazów" ["socially established word combinations which incorporate a certain irregularity, e.g. they include words or word forms not found in the body of free syntactic combinations; the meaning of a multi-word expression is not implied by the meanings of its individual components; the rules of word association are not followed"], as well as phraseological similes and proverbs. A similar approach to phraseology can be found in Indonesian research. This can be seen, for example, in the Badudu (2009) dictionary, which records such phrases as the phraseological unit berhati batu (literally 'to have a heart made of stone'), i.e. 'tak berperasaan' ('heartless, insensitive'), the phraseological simile seperti langit dan bumi (literally 'like heaven and earth'), meaning 'sangat jauh perbedaannya; sangat berlawanan' ('a very big difference; strong opposition'), and the proverb bahasa menunjukkan bangsa (literally 'one's language reflects one's national character'), i.e. 'tutur kata yang sopan menunjukkan asal-usul yang tinggi' ('one's polite words reflect one's noble origin/ancestry'); 'bahasa yang teratur menunjukkan peradaban yang tinggi' ('an orderly language reflects an advanced civilization').

In the context of the Indonesian language, the first two types of units are referred to by the hyperonyms ungkapan or idioms (Chaer, 2007:126-127, 204)-these correspond to the Polish term frazeologizm or multi-word expression (Lewicki \& Pajdzińska, 2001:315). In Polish phraseology research, use is also made of the notion of idiom. Idioms are multiword expressions whose established meanings differ fundamentally from the meanings of their individual components (Lewicki \& Pajdzińska, 2001:318; see also Zakrzewski, 2002). Indonesian literature offers a similar definition for the term ungkapan. For instance, Chaer (2002:vii, 2007:204) states that ungkapan is a word or a combination of words whose meaning cannot be derived from the (lexical and grammatical) meanings of individual components. The fact that the meanings of multi-word expressions are non-compositional and global has also been noted by other researchers (see e.g. Kridalaksana, 1993:80; Badudu, 1992:154; Suwandi, 2008:96; Djajasudarma, 2013:20; Pateda, 2010:230-233). Note that the status of idiom, or-more broadlythat of expression, is reserved for associations of at least two words.

As was mentioned earlier, the linguistic units referred to as ungkapan/idiom ('expression'/'idiom') in the Indonesian language also include similes such as seperti cakar ayam (literally 'like a chicken claw', i.e. 'a scrawl, illegible handwriting') and seperti labu dibenam (literally 'like a sunken pumpkin', i.e. 'very arrogant') and word associations such as daftar hitam (literally 'black list', i.e. 'a list of people, organizations, etc., that are disapproved of or that are to be punished or avoided'), pakaian kebesaran (literally 'oversized clothes', i.e. 'full 
dress/uniform'), koran kuning (literally 'yellow newspaper', i.e. 'the type of newspaper that relies on sensationalism and lurid exaggeration to attract readers'). The latter are referred to as phrasemes. Phrasemes (multi-word expressions) are set phrases whose meanings lie within the semantic scope of the semantic pivot, although the multi-word expression as a whole is semantically irregular (Lewicki \& Pajdzińska, 2001:319). The body of Polish phrases (multi-word expressions) includes such similes as biaty jak śnieg (literally 'white as snow', i.e. 'snow-white') 'very white', głupi jak osiot (literally 'dumb as a donkey') 'very stupid', brudny jak świnia (literally 'dirty as a pig') 'very dirty'.

Indonesian literature has adopted an alternative way to structure such units. It distinguishes between full idioms (idiom penuh) and semi-idioms (idiom sebagian). The former (such as meja hijau literally 'green table', i.e. 'the court', kambing hitam literally 'black goat', i.e. 'fall guy') form an integral indivisible whole. They are made up of components which lose their original lexical meanings in specific configurations. Semi-idioms, in turn (e.g. lapangan hijau literally 'green field', i.e. 'soccer field', pasar gelap literally 'dark market', i.e. 'black market') contain a component (lapangan 'field', pasar 'market') which retains its lexical meaning (see Chaer, 2007:127; 2012:296; 2013b:75; Suwandi, 2008:96).

To complete this overview of approaches and methodologies, it is appropriate to note the difference in usage between the Indonesian concepts of ungkapan and idiom. According to Chaer (2002:viii; 2007:204), the term ungkapan is used in rhetoric, whereas idiom is reserved for semantic studies. The same author also observes that units referred to as ungkapan are open-ended and may be generated ad hoc, whereas idioms are set phrases which appear in a specific invariable form and constitute a close-ended set (Chaer, 2002:viii).

McCarthy and O'Dell (2008) state that idioms are connected with the themes of animals, the sea, sports, parts of the body, food and drink, colours, names of people and places, sight, hearing, taste, smell and touch. We use idioms to describe physical appearance, character and personality, feelings and emotions, work and success, health and illness.

According to Maisa and Karunakaran (2013), many idioms come from a time when far more people worked on the land, there are the large number of idioms which refer to farm animals. Some idioms are formed from rural life, transport. Many idioms have entered into languages from the world of sports and entertainment, from literature and history, the Bible, science and technology.

The present article focuses on describing Indonesian set phrases viewed against Polish collocations. They are examined by a qualitative method. The pairings include Indonesian and Polish set phrases which (1) reflect identical observations and experiences of the communication communities (seen in convergent lexical connotations ascribed to the same components in phrases that are identical or similar in terms of their structures and meanings, or convergent lexical connotations ascribed to the same components in phrases that differ in structure and meaning); and (2) exhibit corresponding differences. In most cases one of the following applies: (type a) Indonesian phrases express the same or similar content as Polish ones but invoke different images-identical or similar lexical connotations are ascribed to different referents (this includes Indonesian phrases containing components that refer to phenomena unknown in Polish culture); (type b) Indonesian phrases differ in meaning from the Polish ones and contain components referring to phenomena that are known to the Polish communication community but come with connotations that do not exist in that community.

The main focus of the description is on the latter type of set phrases, which reveal differences in the way the language organizes the world in the Indonesian and Polish communities. 


\section{SET PHRASES REVEALING CONVERGENT OBSERVATIONS AND EXPERIENCES}

\section{Set Phrases Featuring a Human Body Part}

Before considering Indonesian expressions that are of cultural relevance, it is worth noting the units that bear testimony to the similarity of experience between members of these geographically and culturally distant communities. A substantial proportion of Polish and Indonesian word associations follow an identical or a similar lexical pattern, which reflects similarities in the way reality is perceived within both communities. Consider certain selected examples. There are phrases in both Indonesian and Polish which reflect awareness of a specific symptom associated with death: menutup mata (lit. 'to close one's eyes'), 'meninggal; wafat' ('to die'); zamknać oczy (lit. 'to close one's eyes') 'to die'. The Indonesian expression menutup mata additionally means 'tidak mau tahu; tidak ambil peduli', i.e. 'not to care to know; be indifferent'; a similar semantic value can be found in the Polish expressions przymknać, przymrużyć, zamknać na coś oko/oczy (lit. 'to shut one's eyes to something'), meaning 'to look the other way, turn a blind eye, tolerate, pretend not to see something bad or wrong'. Both phrases rely on the mechanism of metonymy, as they refer to the customary image of a dead person whose eyes are shut.

Another example is the fact that both cultures give positive connotations to the head, a vital part of the human body. The head is seen as crucial for mental faculties and psychological experience, for the reason that it contains the brain. Since the brain is used for thinking, its presence is viewed as a sign of proper mental processes. A person who responds, speaks or behaves contrary to accepted standards is thought to lack a brain under his/her skull (Tyrpa, 2005:146). Such a view of human mental faculties has generated the Indonesian expression kepala kosong (lit. 'empty-headed') and the Polish expression pusta glowa (lit. 'empty head'; with its stylistic variants pusty teb and pusta pała lit. 'empty nut') denoting a mentally insane or dumb individual.

\section{Set Phrases Featuring Names of Animals}

Note that phrases which derive from similar lexical connotations may assume different structures and semantic values. This can be well demonstrated by means of zoonymic (i.e. animalistic) phraseological units. An example of the similarities between the connotations which Poles and Indonesians ascribe to specific animals is provided by the phrase melangkahi ular (lit. 'to step on a snake') meaning 'melakukan sesuatu yang berbahaya' ('to do something dangerous'). The origin of the expression can easily be explained by reference to common perceptions of snakes. Understandably, stepping on an animal as feared as the snake, whose bite is known to be dangerous, can be seen as putting oneself in harm's way. A similar connotation led to the coining of the Polish idiom mieć węża w kieszeni (lit. 'to have a snake in one's pocket'), which means 'to be tight-fisted or parsimonious' (as one would not reach into a pocket, a common place to keep money, if one risked encountering a snake there).

\section{SET PHRASES REVEALING DIVERGENT OBSERVATIONS AND EXPERIENCES (TYPE A)}

Moving on to expressions reflecting the specific realities found in the regions populated by the Indonesian speech community, the author has matched Indonesian and Polish expressions whose idiomatic meanings are the same despite relying on different imagery. This concerns Indonesian expressions which describe the same phenomena differently than the Polish language does. Reference will also be made to Indonesian expressions motivated by observations which are not preserved in Polish phrases. Note that the differences may be driven by two factors. One of them is reliance on references to items not found in the Polish cultural environment, while the other is the non-relevance and marginalization of specific features of items which are common to both communities. 


\section{Set Phrases Featuring Names of Animals}

Both Indonesians and Poles speak of people of limited intelligence by reference to birds, whose small heads are seen as a sign of dim wit (Szerszunowicz, 2011:213). References to dumbness are made using phrases whose lexical components include the word otak ('brain'), as in otak ayam (lit. 'chicken-brain'), cf. the Polish kurzy móżdżek (lit. 'chicken brain'; also ptasi móżdżek, lit. 'bird brain'). Polish also has an expression referring to another animal, the calf: mózg (rozum) cielęcy (lit. 'calf-brain/wit'). Indonesians ascribe dumbness to a mammal which does not naturally occur in Poland and a crustacean which does not traditionally appear on Polish menus. These are the domestic buffalo (a domesticated variety of the water buffalo) and the shrimp, as seen in the idioms otak kerbau (lit. 'buffalo brain') and otak udang (lit. 'shrimpbrain'), both of which mean 'tolol; bodoh' (i.e. 'dumb').

Both Indonesian and Polish have phraseological units denoting immature infatuation. In the Polish language, the meaning is expressed by reference to a young animal. Specifically, it relies on the use of an adjective derived morphologically from the noun szczenie ('a puppy') to form the expression szczenięca mitość (lit. 'puppy love'). The same feature is expressed in Indonesian culture using the noun monyet ('monkey'): cinta monyet (lit. 'monkey love') 'cinta pertama yang melanda anak remaja' ('a youth's first love').

The Indonesian view of avid readers is also distinctive, being expressed in a phrase based on an animal different from that used in the Polish counterpart. The Polish term mól ksiązkowy (lit. 'book moth'), i.e. 'bookworm', becomes kutu buku (lit. 'book louse') in Indonesian. The phrase actually has a broader meaning. It denotes a diligent student ('sangat gemar membaca; sangat rajin belajar'-'to be into reading/derive pleasure from reading; study hard'). The Indonesian expression derives from the image of a louse which feeds meticulously on the human scalp amidst hundreds of thousands of hairs.

Interesting conclusions concerning perceptions of reality can be drawn from a study of expressions used to denote enthusiasm which arises suddenly and dies away quickly. Poles express the idea with the phrase stomiany zapat, ogien' (lit. 'straw enthusiasm, straw fire'), i.e. 'short-lived enthusiasm, a flash in the pan', a reference to the fact that straw is highly flammable and burns violently and rapidly. These characteristics of straw are used to build collocations referring to the human mind (Pajdzińska, 1988:74). Indonesians, in their turn, associate being 'short-lived and highly changeable' with the temperature of animal fecal matter. The idiom hangat-hangat tahi ayam (lit. 'hot as chicken droppings') derives from the observation that chicken excrement is quick to lose heat.

The lexical unit udang ('shrimp') features also in the intensive comparative phrase seperti udang dipanggang (lit. 'as a roasted shrimp') i.e. 'merah sekali (karena malu dan sebagainya)' ('very red (out of embarrassment, etc.)'). Such images are alien to Polish culture. Equivalent phraseological units in the Polish language are based on a different animal: spiec raka, raczka (lit. 'to flare up as crayfish') i.e. 'redden or blush out of embarrassment'.

\section{Set Phrases Featuring Names of Colours}

In Polish similes, redness is associated with such plants as the beet or the peony, as in czerwony jak burak (lit. 'red as a beetroot') and czerwony jak piwonia (lit. 'red as a peony'). In Indonesia, intense redness is invoked by referring to the lotus, as in the phrase merah padam (lit. 'red (as) a lotus'), which semantically means 'merah sekali (tentang muka ketika marah atau malu)' ('very red (of one's face in anger or embarrassment)'). It should be explained that in the analysed word combination the component padam is the result of 
metathesis (Chaer 2013a:104; Muslih 2008:125), which has transformed the lexeme padma 'lotus' into the form padam ('lotus').

Both cultures use color to describe human nature (compare for instance berhati emas, lit. 'to have a golden heart' and zlote serce, lit. 'heart of gold'). Both cultures use the same evaluative connotations with specific colors, as in the Indonesian simile hitam bagai pantat belanga (lit. 'black as the bottom of a (clay) pot') 'sangat buruk (tentang tabiat seseorang)' ('very evil (about a person's character)') and the Polish expression czarny charakter (lit. 'a black character'), referring to a person who is evil, perverse or black-hearted. The above examples illustrate the negative evaluative connotations of the color black as established in both cultures. In the Indonesian expression, reference is made to a culturally determined standard of blackness, the charred pot bottom.

It is appropriate at this point to look into other components of the non-linguistic reality with which Indonesians associate blackness. Two multi-word expressions feature names of creatures stereotypically linked with that color. These are hitam lotong/lutung (lit. 'black (as) a monkey') and hitam kumbang (lit. 'black (as) a beetle'). Both carry the meaning of 'very black'. No such association can be found in the Polish system, where the color black is commonly linked with the night (czarny jak noc, lit. 'black as night'), dirt (czarny jak (święta) ziemia, lit. 'black as (holy) ground/soil'), coal (czarny jak węgiel, lit. 'black as coal'), tar (czarny jak smoła, lit. 'black as tar'), and ebony (czarny jak heban, lit. 'black as ebony'), etc.

\section{Set Phrases Featuring Names of Plants or Their Parts}

The connotations of the nouns pisang ('banana') and tebu ('sugarcane'), both of which items are traditionally less familiar in Polish culture, are manifested in the phrases dapat tebu rebah (lit. 'to receive fallen sugarcane') and mendapat pisang terbuka (lit. 'to receive an open banana'). Both expressions can be defined to mean 'mendapat untung' ('to receive a gain or benefit'). The meaning derives from the awareness that harvesting sugarcane (a plant used in Indonesia and elsewhere to produce sugar), which grows to 2 to 6 , sometimes even 8 meters in height and has a stalk diameter of approximately 2 to 7 centimeters, can be a grueling task. On the other hand, to get to the soft flesh of a banana, one needs to open its peel. None of these observations is reflected in Polish expressions. The Polish word banan ('banana') only appears in two phrases (in common usage). These are bananowa mtodzież (lit. 'banana youth'), i.e. 'young people spoiled by excessive luxury, youngsters who live careless lives and sponge off their parents relying on their social status and wealth', and bananowa republika (lit. 'banana republic') 'a contemptuous term for a small, weak and socially and politically unstable state, often dependent on another (used commonly in reference to Central American countries)'. Sugarcane does not naturally occur in Poland (neither do banana trees, but in contrast to sugarcane, bananas are well-known and popular among consumers). Sugarcane grows exclusively in the tropics, and cane sugar is not as popular in Poland as beet sugar. It is because of the sugarcane's "foreignness" that no connotations have evolved to affect the secondary meanings of phrases, the semantic structure of derivatives, fixed similes or other expressions. No such units can be found in the lexical and semantic systems of the Polish language. Note also that the Polish language expresses the meanings of the above Indonesian phrases with the Bible phrase manna $z$ nieba (spadta komuś) (lit. 'manna from heaven'), meaning 'unexpected profit, a windfall, an undeserved benefit'.

A similar meaning is expressed in Indonesian by a phrase referring to a fruit which is generally unknown in Poland. The fruit, durian, appears in the simile bagai mendapat durian runtuh (lit. 'as if to receive a fallen durian') meaning (mendapat keuntungan yang tidak tersangka-sangka atau tidak dengan bersusah payah', that is 'to receive an unexpected gain or obtain one effortlessly'. 
Indonesians perceive the durian as precious and hard to come by. The fruit is valued for its unique taste and is indeed hard to obtain as it grows in tall trees. To reach its soft flesh, one has to penetrate a thick prickly shell, which also requires substantial effort. Finally, the durian is fairly expensive compared with other types of fruit.

Another example of a culturally-relevant Indonesian idiom is nasi jadi bubur (lit. '(cooked) rice turned into gruel'), meaning 'telah terjadi; sesuatu yang tidak bisa diubah lagi' ('it has happened; something that cannot be undone'). An equivalent expression in Polish is płakać nad rozlanym mlekiem (lit. 'to cry over spilled milk'), i.e. "worry about something that has already happened and cannot be fixed'.

Indonesian phraseological units abound with references to rice, a staple food in that country. In Indonesian culture, rice has a status equivalent to that of bread in Poland. This is evidenced by the Indonesian phrase kalau belum makan nasi belum makan, which translates as 'if you haven't had rice yet, you haven't had anything'. The significance of rice is further reflected in the semantic and lexical segmentation of non-linguistic reality. Indonesians use four separate equivalents to the Polish noun $r y \dot{z}$, i.e. 'rice': these are padi 'rice growing in a field', gabah 'unhulled rice', beras 'a husked grain of rice prepared for cooking', and nasi 'cooked rice'. The significance of rice in Indonesia explains the secondary meaning of the word nasi, namely 'rezeki', i.e. 'basic necessities of life, daily food, income, earnings'. This additionally explains the semantics of such idiomatic expressions as mencari nasi (lit. 'to look for rice') 'bekerja' ('to work') and mencari sesuap nasi (lit. 'look for a bite of rice') 'bekerja untuk mendapatkan rezeki' ('work for money'). In Poland, similar connotations are associated with the word chleb ('bread'), one of whose meanings is 'livelihood, living, wages, employment', and which can also be found in such expressions as ciężki kawatek chleba (lit. 'a hard piece of bread'), i.e. 'money or means earned by hard work', lekki chleb (lit. 'light bread'), i.e. 'easy money, light work', iśćlpójść za chlebem (lit. 'to follow bread'), i.e. 'to engage in a search for employment, livelihood', pracować ciężko na kawatek chleba (lit. 'work hard for a piece of bread'), i.e. 'work hard for a modest living'.

\section{SET PHRASES REVEALING DIVERGENT OBSERVATIONS AND EXPERIENCES (TYPE B)}

\section{Set Phrases Featuring Names of Animals}

Differences in the attribution of characteristics to animals can be seen in further multi-word expressions. One association unknown in the Polish speech community is that made in reference to the crocodile in the Indonesian idiom buaya darat (lit. 'land crocodile'), which denotes a crook as well as a womanizer ('penjahat (pencuri, pencopet, dan sebagainya)'; 'penggemar perempuan'-'a criminal (thief, pickpocket, etc.)'; 'a ladies' man'). A partial equivalent in Polish (the partiality arising from the fact that it corresponds only to the second meaning of the Indonesian expression) refers to a different animal: lew salonowy (lit. 'the salon lion') denotes 'a man who coquets and seduces women' (also colloquially referred to as pies na baby, lit. 'a ladies' dog', i.e. a 'playboy'). Negative connotations with the crocodile can also be found in the Indonesian expression buaya pasar (lit. 'market crocodile') describing a small-time crook who prowls predominantly in markets ('penjahat kecil di pasar'-'petty criminal in a market') or a pickpocket (as defined by Kamus Besar Bahasa Indonesia, 2008). The only Polish phrase to refer to this animal uses the adjective krokodyli, i.e. 'of a crocodile' in the expression krokodyle tzy (lit. 'crocodile tears'), i.e. 'insincere, false tears or faked grief and compassion'.

Rats are an integral part of Indonesian life. They roam the streets, crawl into sewage systems and rummage through garbage. They undermine building foundations, damage windows and munch through food containers. 
They are a scourge not only in cities, but also in rural areas, where they devour rice and other cereals. They are also known for spreading multiple diseases (Torchia, 2007:13-14). Being aware of these issues, one can easily identify the reasons for the association of particular meanings with expressions referring to rats. For instance, dimakan tikus (lit. 'eaten by a rat) and seperti tikus jatuh di beras (lit. 'as a rat that fell into rice') appear to be self-explanatory. The former refers to the regular and gradual stealing of something ('dicuri orang sedikit demi sedikit') whereas the latter describes huge joy, a stroke of luck, propitious or desirable circumstances ('senang sekali; kejadian yang sangat enak'). Incidentally, note that the Indonesian language also features the semi-idiom jalan tikus (lit. 'rat street') denoting a narrow winding street ('jalan sempit dan berlikuliku'). There are a number of other rat-based expressions (such as ditebuk tikus, lit. 'full of ratinflicted holes'- 'sudah hilang kegadisannya (sudah tidak gadis lagi)', 'lost virginity (no longer a virgin)'; seperti tikus masuk perangkap, lit. 'as a rat that walked into a trap'-'orang yang sudah kehilangan akal; amat gelisah', 'a reference to a man who has lost his marbles; (of a man) very uneasy';seperti tikus masuk rumah, lit. 'as a rat who entered a home'-'orang yang kecewa karena tidak terpenuhi harapannya', 'a reference to a man who is disappointed after his hopes have been dashed') showing that the rat has a much broader range of connotations in Indonesian culture than it does in Poland. References to rats in Polish expressions are basically limited to three phrases: szczur ladowy (lit. 'a land rat'), i.e. 'a landsman', 'used in reference to a person who permanently remains on land, easily becomes seasick and is ignorant of maritime affairs (as opposed to fishermen and seamen)'; szczurza nora (lit. 'a rat's burrow') 'a filthy, miserable and murky room or dwelling'; and uciekać jak szczury z tonacego okrętu (lit. 'run like a rat deserting a sinking ship') 'to run quickly having sensed trouble or danger'.

\section{CONCLUSION}

The preliminary analysis of Indonesian phraseology that has been presented here reveals similarities as well as differences. The similarities result from convergence in people's perceptions of the realities surrounding them. There can hardly have been any borrowings occurring between the languages, in view of the geographical distance between the communication communities in question-rather, the similarities result from the operation of the principle of identical or similar associations. As a consequence of this, Indonesians and Poles have the same perceptions of death, and they ascribe identical characteristics to foolish people and snakes. On the other hand, the observed discrepancies (on which the present analysis has focused) result from cultural differences. There are Indonesian phrases which express the same or similar concepts in ways that differ from those applied in Polish. These are underpinned by different images of certain parts of reality. Furthermore, Indonesian connotations can be found which reflect certain properties of objects or phenomena which are not observed (or are not considered significant) in the Polish language community. There are also set phrases containing words referring to phenomena which are largely unknown to Polish speakers. For instance, durian and sugar cane do not occur naturally at the latitudes where Poland lies, and those plants are practically unknown to Polish culture.

An abundance of idiomatic expressions are produced in every culture and their languages. Boers and Demechenleer (2001:255-257) affirm that some evident idioms existing in one culture, may be not so obvious in another. Moreover, learners of that language may conceive distinct images of the same idiom. Difficulties in comprehension can occur between cultures which are less related whereas more similar cultures may have more subtle differences in idioms.

The differences between Indonesian and 
Polish idioms are connected with geographical environment, historical events, manners and customs and religious beliefs. This issue requires a separate description.

The specific nature of the linguistic units investigated in the study makes them extremely interesting phenomena. Their observation allows one to capture the way communities think and respond to reality, to discover the traditions and explore the experience of members of the Indonesian community (Goshkheteliani, 2013; Berthemet, 2011), and finally to ascertain the extent of overlaps between the world perceptions existing in specific linguistic areas (Nagórko, 1994:11). By contrasting such remote languages, belonging to distinct cultures that differ substantially in terms of religion, political system and form of civilization, valuable observations have been made pertaining to both the universality as well as the relativity of languages (construed as the coexistence of or competition among various linguistic approaches to describing the world).

Indonesian expressions provide interesting material for exploring the spiritual and material history of that country. Their analysis additionally contributes to the advancement of translation theory, research on bilingual phraseological units, and the theory of language teaching.

\section{REFERENCES}

Adelaar, Alexander. (2005). "The Austronesian Languages of Asia and Madagascar: a Historical Perspective". In Alexander Adelaar \& Nikolaus P. Himmelmann (eds.) The Austronesian Languages of Asia and Madagascar. London and New York: Routledge, 8-26.

Alvi, Hasan, Dardjowidjojo, Lapoliwa, Hans \& Moeliono, Anton M. (2003). Tata Bahasa Baku Bahasa Indonesia. Jakarta: Balai Pustaka.

Ana, Haerun. (2014). "Contrastive Study of Aspect between Muna and Indonesian Languages". Jurnal Humaniora, 26, 84-92.
Anusiewicz, Janusz. (1995). Lingwistyka kulturowa. Zarys problematyki. Wrocław: Wydawnictwo Uniwersytetu Wrocławskiego.

\& Skawiński Jacek. (1996). Stownik polszczyzny potocznej. Warszawa-Wrocław: Wydawnictwo Naukowe PWN.

Badudu, Jusuf S. (1992). Cakrawala Bahasa Indonesia II. Jakarta: Gramedia.

(2009). Kamus Ungkapan Bahasa Indonesia. Jakarta: Rineka Cipta.

Bartmiński, Jerzy. (2007). Stereotypy mieszkaja w języku. Studia etnolingwistyczne. Lublin: UMCS.

. (2009). Językowe podstawy obrazu świata. Lublin: UMCS.

Bąba, Stanisław \& Liberek, Jarosław. (2001). Słownik frazeologiczny wspótczesnej polszczyzny. Warszawa: PWN.

Berthemet, Elena. (2011). "Motivation of Idioms and Proverbs in a Contrastive Perspective". In J. Szerszunowicz, B. Nowowiejski, K. Yagi \& T. Kanzaki (eds.) Research on Phraseology in Europe and Asia: Focal Issues of Phraseological Studies. Vol. 1. Białystok: University of Bialystok Publishing House, 229-245.

Boers, Frank \& Murielle Demecheleer. (2001). "Measuring the Impact of Cross-Cultural Differences on Learners' Comprehension of Imageable Idioms". ELT Journal, 55/3, 255-262.

Burszta, Wojciech. (1986). Język a kultura w myśli etnologicznej. Wrocław: Polskie Towarzystwo Ludoznawcze.

Chaer, Abdul. (2002). Kamus Ungkapan Bahasa Indonesia. Jakarta: Rineka Cipta. . (2007). Leksikologi \& Leksikografi Indonesia. Jakarta: Rineka Cipta.

(2011). Tata Bahasa Praktis Bahasa Indonesia. Jakarta: Rineka Cipta.

(2012). Linguistik Umum. Edisi baru. Jakarta: Rineka Cipta. . (2013a). Fonologi Bahasa Indonesia. Jakarta: Rineka Cipta. 
(2013b). Pengantar Semantik Bahasa Indonesia. Jakarta: Rineka Cipta.

Djajasudarma, Fatimah T. (2013). Semantik 2. Relasi Makna Paradigmatik-Sintagmatik-Derivasional. Bandung: Refika Aditama.

Dobrovol'skij, Dmitrij \& Piirainen, Elisabeth. (2005). Figurative Language: Cross-cultural and Crosslinguistic Perspectives. Oxford: Elsevier.

Forshee, Jill. (2006). Culture and Customs of Indonesia. Westport-London: Greenwood Press.

Goshkheteliani, Irine. (2013). "Idioms in Crosscultural Communication". In J. Szerszunowicz, B. Nowowiejski, K. Yagi \& T. Kanzaki (eds.) Research on Phraseology Across Continents. Vol. 2. Białystok: University of Bialystok Publishing House, 19-36.

Jedamski, Doris. (1987). Sprachpolitik in Indonesien. Anmerkungen zum Verhältnis von National- und Regionalsprache und Schriftlichkeit. Hamburg: Hamburg University Press.

Kamus Bahasa Indonesia. 2008. Jakarta: Pusat Bahasa.

Kamus Besar Bahasa Indonesia. Edisi keempat. 2008. Jakarta: Gramedia.

Keraf, Gorys. (1990). Linguistik Bandingan Tipologis. Jakarta: Gramedia.

Kłosińska, Anna, Sobol, Elżbieta \& Stankiewicz, Anna (prod.). (2005). Wielki słownik frazeologiczny $P W N$ z przystowiami. Warszawa: PWN.

Kridalaksana, Harimurti. (1993). Kamus Linguistik, Jakarta: Gramedia.

Lewicki, Andrzej M. \& Pajdzińska, Anna. (2001). "Frazeologia". In J. Bartmiński (ed.) Wspótczesny język polski. Lublin: UMCS, 315-333.

Lewicki, Andrzej M. (2003). Studia z teorii frazeologii. Łask: Oficyna Wydawnicza Leksem.

Lisowski, Tomasz. (2004). "Yeoucheoreom gyohwalhan czyli chytry jak lis. Kilka uwag o genezie polskich i koreańskich frazeologizmów". In J. Liberek (ed.) Studia nad polszczyzna wspótczesna $i$ historyczną. Prace dedykowane Profesorowi Stanisławowi Babie w 65-lecie urodzin. Poznań: Wydawnictwo Poznańskie Studia Polonistyczne, 189-196.

Maisa, Sridhar \& Karunakaran, T. (2013). "Idioms and Importance of Teaching Idioms to ESL Students: A Study on Teacher Beliefs". Asian Journal of Humanities and Social Sciences, 1/1, 110-120.

McCarthy, Michael \& O’Dell Felicity. (2008). English Idioms in Use. Cambridge: Cambridge University Press

Muslich, Masnur. (2008). Fonologi Bahasa Indonesia. Tinjauan Deskriptif Sistem Bunyi Bahasa Indonesia. Jakarta: Bumi Aksara.

Nagórko, Alicja. (1994). 'Z problemów etnolingwistyki-jak porównywać języki i kultury?". Poradnik Językowy, 4, 4-14.

Nur, Tajudin. (2011). “Analisis Kontrastif Perspektif Bahasa dan Budaya Terhadap Distingsi Gender Maskulin Versus Feminin dalam Bahasa Arab dan Bahasa Indonesia". Jurnal Humaniora, 23, 269279.

Pajdzińska, Anna. (1988). “Udział konotacji leksykalnej w motywacji frazeologizmów”. In J. Bartmiński (ed.) Konotacja. Lublin: UMCS, 67-82.

Pateda, Mansoer. (2010). Semantik Leksikal. Jakarta: Rineka Cipta.

Skorupka, Stanisław. (1967). Stownik frazeologiczny języka polskiego. Vol. 1-2. Warszawa: Wiedza Powszechna.

Sneddon, James N. (2003). The Indonesian Language. Its History and Role in Modern Society. Sydney: UNSW Press.

Suwandi, Sarwiji. (2008). Semantik. Pengantar Kajian Makna. Yogyakarta: Media Perkasa.

Szerszunowicz, Joanna. (2011). Obraz człowieka w polskich, angielskich $i$ włoskich leksykalnych $i$ frazeologicznych jednostkach faunicznych. Białystok: Wydawnictwo UwB.

Torchia, Christopher. (2007). Indonesian Idioms and Expressions. Colloquial Indonesian at Work. Singapur: Tuttle Publishing. 
Tyrpa, Anna. (2005). Frazeologia somatyczna. Zwiazki frazeologiczne o znaczeniach motywowanych cechami części ciała $w$ gwarach polskich. Łask: Oficyna Wydawnicza Leksem.

Wijana, I Dewa Putu. (2003). "Indonesian Vowels and Their Allophones". Jurnal Humaniora, 15, 39-42.

Zakrzewski, Paweł. (2002). "W sprawie definicji idiomu". Acta Universitatis Lodziensis. Folia Linguistica, 42, 19-23.

Zaręba, Leon \& Szpila, Grzegorz. (2007). "Problemy frazeologii konfrontatywnej w perspektywie leksykograficznej na przykładzie języka francuskiego". Problemy Frazeologii Europejskiej, 8, 33-44. 